\title{
Ensomhet og selvmord
}

\author{
Ved Elin Anita Fadum
}

\section{Selvmord er kanskje den mest ensomme av alle handlinger, eller sagt på en annen måte: Selvmordet kan kanskje beskrives som den ytterste konsekvens av opplevd ensomhet. I denne artikkelen vil jeg belyse ensomhetsbegrepet og se på ensomhet som risikofaktor for selvmord og selvmordsforsøk.}

Selv om forskning ikke har etablert ensomhet som en kausal årsaksfaktor for selvmord, viser en rekkestudier at ensomhet er en risikofaktor for selvmord og selvmordsforsøk, enten alene eller i samspill med andre kjente risikofaktorer (Stravynski \& Boyer, 2001; Heikkinen, 1994; Ekeberg \& A argaard, 1991; Joiner \& Rudd, 1996). Samtidig er det mange mennesker som lever med en stor ensomhetsfølelse uten at de noen gang tenker på å ta sitt eget liv. M ange vil til og med karakterisere sin ensomhet som noe sunt og nærende. $\mathrm{H}$ va er det ved ensomheten som gjør at den for noen kan være livstruende, mens den for andre er forbundet med styrke, håp og frihet? G år det an å lindre opplevd ensomhet og dermed redusere suicidalimpulser? D ette er spørsmål som tas opp i denne artikkelen.

\section{Hva menes med ensomhet?}

\section{Ensomhet i språket}

Ensomhet er vanskelig å definere og kvantifisere, men også vanskelig å beskrive. I det norske språket finnes det ingen synonym for ensomhet, ei heller noen motsetning - å ikke være ensom. Det nærmeste vi kommer en betegnelse for det motsatte av ensomhet er kanskje opplevelsen av fellesskap eller samhørighet. Ensomhet har mange ansikt og kan oppleves i mange ulike situasjoner og former, den kan ha en sterk eller svak intensitet, og det er svært mange følelser forbundet med opplevelsen av ensomhet (T horsen, 2005). Derfor går det ikke an å behandle ensomhet som fellesskapets motstykke. $M$ en opplevelsen av ensomhet er med på å fortelle oss hva fellesskap og samhørighet handler om.

U ttrykket alene, men ikke ensom vitner om at mange har en intuitiv forståelse av at ensomhet er noe annet enn det å være alene. I det engelske språket finner vi den samme nyanseringen i begrepene loneliness som er synonymt med smertefull ensomhet, og solitude som betegner de positive sidene ved å være for seg selv. Solitude er betegnelsen på en tilstand preget av ro og frihet til selv å velge sine aktiviteter og tanker. Solitude ansporer til kontemplasjon, kreativitet og ettertenksomhet (Long \& A verill, 2003). Vanligvis blir solitude sett på som en tilstand man velger selv. $M$ an kan for eksempel velge å ta avstand fra et fellesskap, fordi gruppen representerer noe man ikke ønsker å identifisere seg med. Loneliness derimot, forteller om en uønsket distanse til andre mennesker og et savn etter nærhet (Karnick, 2005).

\section{E nsomhet som nœe negativt eller uønsket}

O rdet ensomhet forbindes med en rekke termer med en negativ klang som f. eks forlatt, hjelpeløs, tom, død, naken, sårbar, liten, avvist, ulykkelig, lidende, avsondret, vergeløs, isolert eller glemt ( $\mathrm{N}$ ilsson, 2004).

Platon behandlet ensomhet som en menneskelig drivkraft for å unngå sosial isolasjon. A ristoteles videreførte denne tankegangen om ensomhet som en uønsket følelse ved å hevde at ingen vil velge en tilværelse uten venner. Innenfor sosialpsykologien har ensomhet i stor grad blitt regnet som en smertefull og uønsket tilstand som går forut for, eller følger av et psykopatologisk symptomkompleks (Karnick, 2005). Sett ut i fra en teori om at alle mennesker har en gjennomgående trang til å danne og opprettholde et minimum av varige, positive og betydningsfulle relasjoner omtrent som vâre basale drifter som å spise, drikke etc., blir ensomhet en uønsket tilstand (Baumeister \& Leary, 1995). I følge W eiss har ensomhet ingen positive føl ger for individet, og bør derfor bli behandlet som en sykdom.

W eiss peker på at ensomhet kan skyldes savn av noen å stå helt nær, men ensomhet kan også skylde at personen ønsker seg et større nettverk. Den første formen kaller han følelsesmessig ensomhet, den andre sosial ensomhet (Thorsen, 2005). En kombinasjon av følelsesmessig ensomhet og sosial ensomhet er vanlig (Halvorsen, 2005).

\section{E nsomhet som noe positivt}

Begrepet ensom kan også assosieres med ord som enestående, makeløs eller unik og fortelle om styrke, rettskaffenhet og lojalitet mot seg selv eller andre ( $\mathrm{N}$ ilsson, 2004). U ttrykket i ensom majestet er et bilde på et individ som kommer alene, men allikevel er både sterk, stolt og fryktІøs. Det er mange aktiviteter vi gjør alene som vi verdsetter høyt, for eksempel søvn, drømmer og tenkning ( $\mathrm{H}$ alvorsen, 2005).

Eksistensfilosofene lærer oss at ensomhet er et grunnleggen de trekk ved menneskenes eksistensvilkår. Ensomhet er en smertefull, men helt nødvendig tilstand for at mennesket kan oppnå personlig vekst og frihet, samt knytte meningsfulle forbindel ser til andre (Karnick, 2005). Yalom sier at vi er alle alene i tilværelsen, ikke noe forhold til G ud eller andre mennesker kan oppheve isolasjonen. $M$ en vi kan dele ensomheten på en slik måte at kjærligheten veier opp for isolasjonens smerte (Yalom, 2000).

Kierkegaard hevdet at det er bare gjennom ensomheten at mennesket kan bli kjent med seg selv. $\mathrm{H}$ an mente at man bare kan finne ut av hvem man er ved å akseptere sin frykt for å være ingen (K arnick, 2005). Ensomheten er en kilde til å forstå seg selv som et en eståen de og uerstattelig individ. I følelsen av å være ensom kan den enkelte bli oppmerksom på sitt særpreg i forhold til andre og dermed bli bevisst sin egen identitet og autonomi.

Så, hva er da egentlig ensomhet? Er ensomhet et grunnleggende trekk ved mennesket, som er nødvendig for all menneskelig sameksistens eller en unaturlig tilstand, lidelse eller sykdom?

I sin doktoravhandling Savnets tone i ensomhetens melodi polariserer Brita $\mathrm{N}$ ilsson ensomhet som både helse og lidelse. Ensomhet som helse handler om savn og lengsel, men også håp. I en somhet som lidelse oppleves ubehag, smerte og forlatthet ( $\mathrm{N}$ ilsson, 2004). O pplevd ensomhet kan graderes på en skala fra noe positivt til noe som er negativt. Positiv ensomhet nærer opp under kreativitet, selverkjennelse og modning. $N$ egativ ensomhet handler om fysisk, psykisk eller følelsesmessig fremmedgjøring, eller isolasjon fra seg selv eller andre (Karnick, 2005).

Den danske presten og filosofen K. E. Løgstrup beskrev også ensomhet som i alle fall to ulike former eller typer. Den første formen karakteriserte han som 


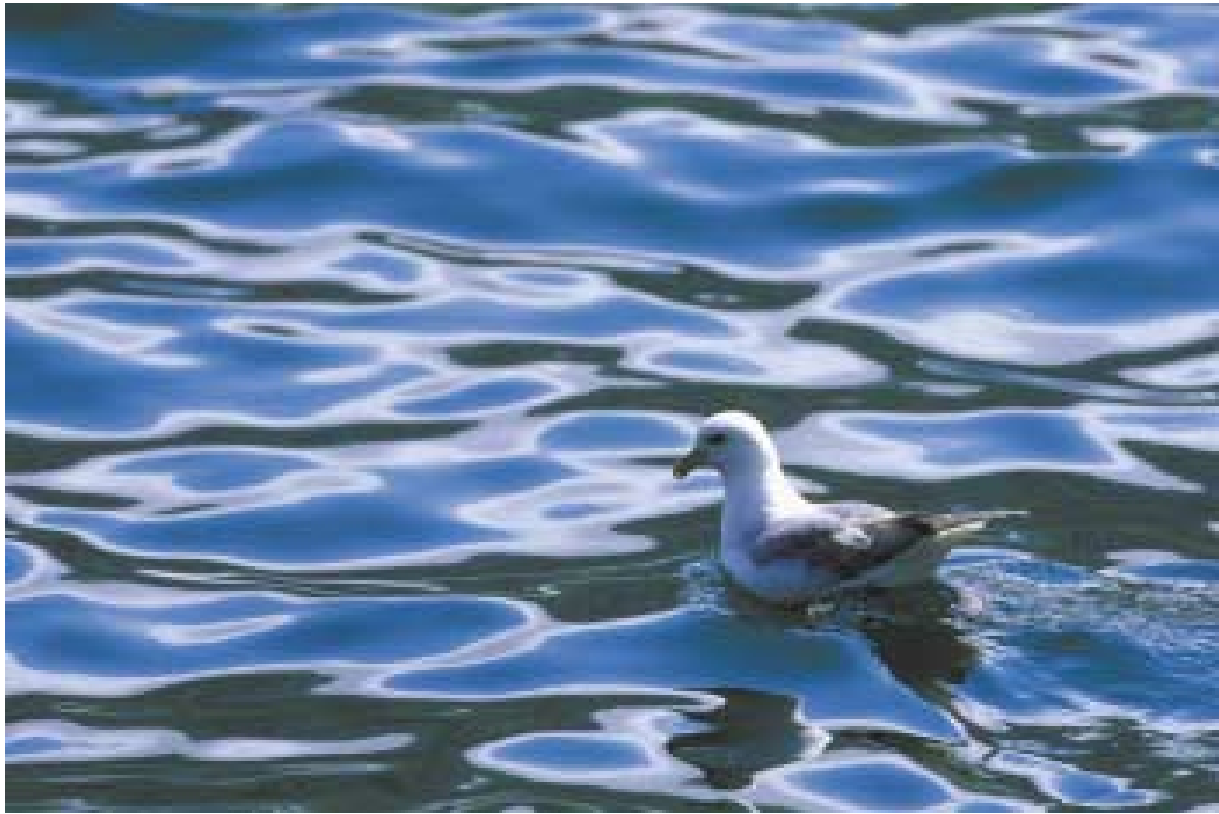

Foto: Rudy Hemmingsen/Scanpix Denmark

fryktelig der mennesket lever i en tom verden hvor andre mennesker ikke kommer en selv nær. I motsetning til dette fryktelige står den velsignede ensomheten som Løgstrup hevdet er en betingelse for all kjærlighet. Det at ethvert individ er lukket inne i seg selv slik at ens følelser er bare ens egne følelser og aldri kan føles av en annen, er selve kjærlighetens incitament. Fordi den andre som jeg elsker ikke kan kjenne min kjærlighet gjennom sine egne følelser, må jeg hele tiden gi uttrykk for den. En kjærlighet som ikke trenger å uttrykkes, blir meningsløs. Likeledes vil det å kjenne den andres kjærlighet til en selv så fullt og helt som den andre kjenner den, falle sammen med en narsissisme som gjør at gleden og takknemligheten over den andres kjærlighet forsvinner (Løgstrup, 1999).

\section{Ensomhet som risikofaktor for} selvmord og selvmordsfors $\emptyset \mathrm{k}$

M ed utgangspunkt i spørsmålet om hva ensomhet er og om det finnes en sammenheng mellom ensomhet og selvmordsfare, ble det gjort systematiske søk i Pubmed og Psyclnfo med søkeordene loneliness, feeling alone, feeling lonely og social isolation. Søkeordene ble kombinert med suicide og suicidal behavior.

Flere undersøkelser viser at ensomhet er en viktig sårbarhetsfaktor for selvmordstanker og selvmordsforsøk. Selvmordsprosessen, fra de første tankene om selvmord til en selvmordshandling med eller uten fatal utgang, preges ofte av en økende grad av ensomhet (Stravynski \& Boyer, 2001; Joiner \& Rudd, 1996).
En vanlig hypotese om sammenhengen mellom ensomhet og sel vmordsrisiko er at ensomheten genererer en ny prediktor for selvmord, som for eksempel smerte, lav selvfølelse eller håpløshet. Joiner og Rudd (1996) har testet ut en slik antakelse og sett nærmere på sammenhengen mellom ensomhet, håpløshet og selvmordstanker. De konkluderer med at forbindel sen mellom de tre fenomenene ikke ligger $i$ at ensomhet genererer håpløshet som igjen kan predikere selvmordsfare. Ensomhet og suicidalitet er snarere forbundet med hverandre ved at de har håpløshet som en felles bakenforliggende faktor (følel sen av håpløshet kan predikere både en somhet og suicidalitet) (Joiner \& Rudd, 1996).

I 2002 ble det gjennomført en nasjonal spørreskjemaundersøkelse blant norske elever (13-19 år) med spørsmål om blant annet sosialt nettverk og psykisk helse. Ett av spørsmålene var $\mathrm{H}$ ar du noen gang forsøkt å ta ditt eget liv? med svaralternativer ja/nei. $15 \%$ av guttene som følte seg ensomme, svarte bekreftende på spørsmålet mot $4 \%$ av de guttene som ikke følte seg ensomme. Blant jentene svarte $22 \%$ av de ensomme at de en eller annen gang hadde forsøkt å ta sitt eget liv mot $11 \%$ av de som ikke følte seg ensomme (Rossow, 2004).

I en studie av personer over 70 år som var innlagt på U llevål sykehus etter selvpåført forgiftning, fant man at ensomhet og isolasjon var den vanligste grunnen pasientene oppga for selvmordsforsøket (Ekeberg \& A argaard, 1991).

Stravynski og Boyer gj ennomførte i 1987 en prevalensundersøkelse blant inn- byggere i Q uebec over 15 år som bodde i private hjem. De hevder på bakgrunn av denne studien at det er en sammenheng mellom ensomhet og selvmordstanker og-forsøk. Denne sammenhengen er sterkere for den følelsesmessige ensomheten enn for den sosiale ensomheten, og risikoen for selvmordsforsøk øker med ensomhetens dybde eller intensitet. I deres un dersøkelse rapporterte $21 \%$ av de som hadde følt seg ensomme ofte om selvmordstanker i motsetning til 2,5 \% av de som ikke hadde følt seg ensomme ofte (Stravynski \& Boyer, 2001).

Ensomhet kan utløses brått og brutalt ved tapet av en som står en nær. En norsk levekårsundersøkelse fra 2002 viste at de som har tapt en nær relasjon, enker, enkemenn og fraskilte, var mer ensomme enn gifte, samboende og ugifte (Barstad, 2004). U ndersøkel ser viser at det å miste en nærstående person øker risikoen for selvmord (Bunch, 1972). D et er særlig blant dem som nylig har blitt enker og enkemenn vi kan finne en livstruende type en somhet preget av tomhet, meningsløshet og håpløshet (Thorsen, 2005) .

En gruppe som er spesielt selvmordsutsatt, er mennesker med psykiske lidelser (Retterstøl et al., 2002). M ennesker med psykiske lidel ser er også svært utsatt for ensomhet som følge av stigmatisering, arbeidsledighet og mangelfulle evner til å knytte og ivareta meningsfulle relasjoner.

Ensomme mennesker bruker ikke nødvendigvis mindre tid sammen med andre enn de som ikke føler seg ensomme, men de bruker mindre tid sammen med venner og familie som kan gi en følelse av å høre til i en gruppe (Baumeister \& Leary, 1995). Durkheim hevdet at det er en sammenheng mellom individets tilbøyelighet til å ta sitt eget liv og graden av individual isme, sosial isolasjon eller ensomhet. $H$ an så på samholdet - mennesker som en kilde til livsstyrkende kraft og betraktet selvmordet som et uttrykk for at forholdet til denne kraften, eller at kraften selv, var blitt forstyrret. $M$ anglende tilfredsstillelse av men neskets grunnleggende behov for tilhørighet og fellesskap kan svekke livslysten med selvmord som følge. Det egoistiske selvmord var D urkheims betegnelse på selvmord hvor den som tok sitt eget liv, hadde levd avsondret fra fellesskapet, i ensomhet eller i sosial isolasjon (Durkheim, 1897/ 2001). 


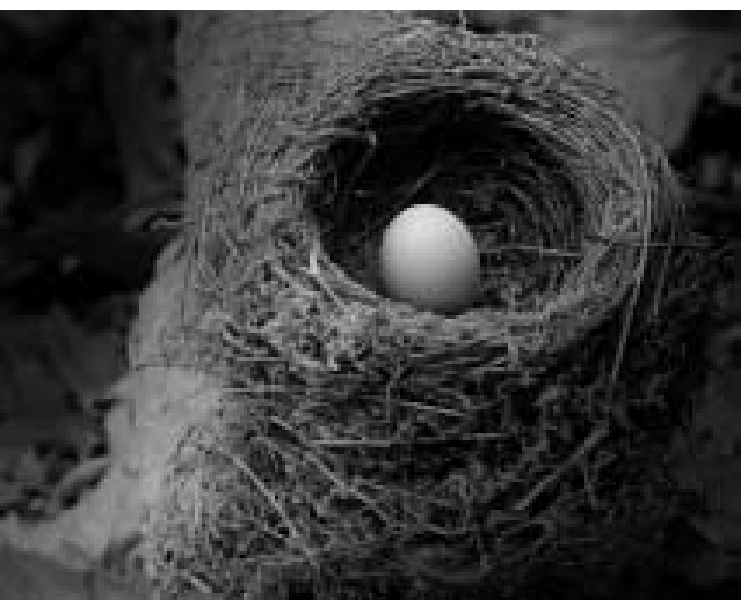

Foto: Peter Mark/Scanpix Denmark

Kan ensomhetsfølelsen lindres?

\section{O pplevelse av nærhet til andre}

H elt sentralt for å gi livet innhold og unnslippe ensomhet er opplevelsen av nærhet til andre. Det er viktig å kunne oppleve samvær når man føler at man trenger det, og møte anerkjennelse for at vi har et behov for å fortelle ærlig om oss selv og våre liv. Vi trenger å være i lag, gråte, le, dele tanker, følelser og opplevelser. M erleau-Ponty hevder at når man opplever seg selv i samspill med en annen, blir den andre personen en del av ens egen selvforståelse. Enhver genuin erfaring av nærhet med en annen beveger en derfor bort i fra ensomheten (Karnick, 2005). O pplevelsen av at noen forstår og kan kjenne seg igjen i smerten og fortvilelsen, kan bidra til å lindre den følelsesmessige en somheten.

\section{Avstand og fornektelse}

$M$ ange kan oppleve en lindring av den ensomheten de erfarer ved å ta avstand fra og fornekte de negative følelsene som ensomheten vekker. Ved å fylle all sin tid til travelhet, for eksempel $\mathrm{i}$ arbeid eller trening, kan man lindre, glemme eller fortrenge sin følelse av ensomhet (H alvorsen, 2005).

$M$ ange en somme finner paradoksalt nok en lindring for sin ensomhet ved å holde andre mennesker på avstand. A vstand til andre virker som en beskyttelse for sårbarheten i det å være ensom. Ved å ikke inngå nære relasjoner unngår man også den smerten og ensomheten som et eventuelt tap kan medføre (Rokach \& Brock, 1998).

\section{A ksept/endret forståelse av ensomhet}

En annen måte å takle ensomhet på er gjennom å akseptere seg selv som en som, lære å sette pris på alenetid som noe positivt og endre sin forståelse av hva ensom- het er. G jennom meningsfulle aktiviteter som oppleves som styrkende, positive og givende kan den frykten som ensomheten ofte vekker, erstattes av følel ser som mestring og kontroll. Dette kan igjen hjelpe den enkelte til å endre sin selvforståelse av det å være en som fra hjel peløs, mislykket og sårbar til selvstendig, uavhengig, sterk og fri.

En studie gjort blant åtte deprimerte kvinner viser hvordan de forandret sitt syn på seg selv som ensomme. Før de fikk behandling mot sin depresjon, oppfattet de seg selv som sårbare, en gstelige, hjel peløse og uten kontroll, fordi de var ensomme. Underveis i behandlingen betraktet de sin ensomhet som synonymt med uavhengighet, håp, styrke, autonomi og evne til selvbestemmelse (Pierce et al., 2003).

\section{R eligiøs tro og deltakelse}

Erkjennelsen av at ensomhet er en eksistensiell og uunngåelig følelse kan bidra til å lindre en somhetens smerte, men kan også gi opphav til en følelse av fremmedgjøring, tomhet eller meningsøøshet. $M$ ange finner lindring for en slik type eksistensiell ensomhet gjennom religiøs tro og deltakelse i religiøse samfunn og ritualer hvor de opplever en følelse av tilhørighet og fellesskap (Rokach, 1990).

\section{Styrke sosial deltakelse}

M ange håndterer ensomheten ved å styrke sitt sosial e nettverk og øke sosial deltakelse. I aktivitetsfellesskap med andre ligger det en mulighet til å knytte nye vennskapsbånd og etablere nære rel asjoner. I 2001 var vel halvparten av den norske befolkningen aktive i frivillige organisasjoner. Betydningen av å styrke de frivillige organisasjonene fremheves for å begrense ensomheten $\mathrm{i}$ vărt samfunn (Barstad, 2004).

Det finnes ingen statlige eller frivillige tiltak i N orge som har som mandat å bekjempe en somhet, men flere frivillige organisasjoner har lenge vært opptatt av ensomheten i vårt samfunn, og har opprettet tiltak mot ensomhet. $N$ orges $R ø d e$ Kors driver blant annet en besøkstjeneste der ensomme mennesker kan fă jevnlig besøk. Frivillighetssentralene rundt om i landet har etablert møteplasser og andre tiltak som egner seg godt for en somme og sosialt isolerte. O rganisasjonen Telefonkontakt for eldre organiserer frivillige tele- fonvenner til å ringe regel messig til de som benytter seg av tjenesten ( $\mathrm{H}$ alvorsen, 2005).

Kirkens SO S er også et eksempel på en frivillig organisasjon som har som mål setting å lindre ensomhet ved å lytte og være til stede for dem som føler at de ikke har noen å vende seg til. $H$ ver fjerde innringer til Kirkens SO S ønsker à snakke om sin ensomhet (Kirkens SOS, 2005). Kan virkelig opplevelsen av ensomhet reduseres på avstand gjennom virtuelle kommunikasjonsmidler som telefon og Internett?

Den som henvender seg til Kirkens SOS og medarbeideren som svarer på henvendelsen er fysisk atskilte, de kjenner hverandre ikke og de møtes an onymt. Tidligere general sekretær i KirkensSOS, Øystein G losli, beskriver dette som en svakhet ved tjenesten ved å si at Kirkens SO S møter ensomhet på avstand ( $\mathrm{G}$ losli, 2002). M otsatt vil jeg hevde at anonymiteten og den fysiske atskillelsen er et av telefontjenestens sterke fortrinn som muliggjør en åpenhet og nærhet det neppe ville vært like lett å skape hvis samtalepartnerne hadde møtt hverandre ansikt til ansikt. Studier av videokonferanser mellom pasient og terapeut har utfordret myten om at fysisk tilstedeværelse er det ideelle og fjernsamhandling er nest best ( $\mathrm{G}$ ammon, 2000). M ange synes det er problematisk å fortelle om sin ensomhet til andre. Det er nærmest tabubelagt å snakke om ensomhet, og mange vil holde sin ensomhet skjult. M uligheten for å være anonym kan gjøre det mindre truende å snakke åpent om seg selv som ensom og redselen for å framstå som tåpelig eller ynkelig reduseres. A nonymiteten og avstanden i det fysiske rom gir en uforpliktende frihet som kan gjøre det mulig å være liten og sårbar i et ekte og nært møte med en annen.

I den tidligere nevnte ungdomsundersøkel sen fra 2002 fant man at tallet blant ungdommer som føler seg ensomme, har gått ned fra 1992 til 2002. Blant dem som oppga at de ikke hadde noen de regnet som sin bestevenn, var andelen ensomme halvert blant guttene og redusert med mer enn en tredjedel blant jentene. Forklaringen på redusert ensomhetsfølelse blant unge kan være at mobiltelefon og Internett, spesielt chat og diskusjonsgrupper, har utvidets ungdommenes, og da spesielt guttenes, sosiale nettverk (Eriksen, 2005). 
Slike funn står i kontrast til oppfatningen om at vi går mot et stadig kaldere samfunn, der ensomheten vokser i takt med at tradisjonelle møteplasser som postkontor, fergel eie, kirke og nærbutikk erstattes av el ektroniske kommunikasjonsmidler uten kontakt ansikt til ansikt. En fjerdedel av den voksne norske befolkning oppga i en levekårsundersøkelse i 2002 å ha vært litt eller mye plaget av ensomhetsfølelse de siste 14 dager. Vi mangler norske data som kan vise utviklingen av ensomhetsfølel se over en lengre tidsperiode, men en undersøkelse fra Vest-Tyskland viste at andelen som ga uttrykk for ensomhetsfølelse, var omtrent den samme i 1998 som 20 år tidligere (Barstad, 2004).

\section{Kan suicidalimpulser reduseres ved å lindre ensomhet?}

Som nevnt øker risikoen for selvmord med ensomhetens dybde eller intensitet. En opplevelse av at noen er til stede, forstår og kan kjenne seg igjen i smerten kan bidra til å lindre ensomhetsfølel sens intensitet og derigjennom muligens redusere suicidalimpulser. Studier har vist at så enkle tiltak som à sende postkort til pasienter som har vært innlagt på sykehus etter selvpåført forgiftning i de første 12 månedene etter utskrivel se reduserer både selvmord og andelen som gjentar en selvpåført forgiftning ( $M$ otto \& Bostrom,

2001; C arter et al., 2005).

M ennesker med et sosialt nettverk som er satt sammen av for få medlemmer eller overfladiske relasjoner uten tilstrekkelig fortrolighet, nærhet og tillit, vil ikke få tilstrekkelig støtte fra andre mennesker når de har problemer. En slik type sosial ensomhet øker sannsynligheten for selvmord som reaksjon på personlige problemer eller krise. Durkheim fant en høyere selvmordstilbøyelighet i protestantiske områder enn i katolske, og tilskrev dette en mer individualistisk livsholdning og mindre deltakelse i felles religiøs virksomhet blant protestanter enn katolikker (G uneriussen, 1997). A ndre undersøkelser støtter Durkheims syn på at det sosiale nettverket i religiøse samfunn kan virke beskytten de mot selvmord (Vijayakumar, 2002). N ærmiljøet, arbeidslivet, religiøse samfunn og frivillige organisasjoner er viktige utgangspunkt for at mennesker kan bygge sosiale nettverk.
Ensomhet opptrer ofte som en komorbid risikofaktor for selvmord i samspill med andre kjente risikofaktorer. I forskningslitteraturen blir også ensomhet som oftest behandlet i sammenheng med andre fenomener som psykisk lidelse, håpløshet, sorg eller smerte, og ikke som et enkeltståen de begrep eller fenomen $i$ seg selv. Ensomhet blir også ofte behandlet synonymt med sosial isolasjon eller det å være alene. Det er vanskelig å sammenlikne forskningsresultater fordi vi mangler enighet om standardiserte definisjoner om hva ensomhet er. Derfor er det også vanskelig å konkludere med om det å lindre ensomhet virker selvmordsforebyggende eller ikke. Det er nødvendig med flere undersøkelser som ser på sammenhengen mellom ensomhet og selvmord, eller studerer nærmere hvordan ensomhet er relatert til andre risikofaktorer for selvmord.

\section{Konklusjon}

I denne artikkelen har jeg gjort rede for ensomhet som et man gfoldig fenomen med både positivt og negativt innhold. Ensomhet er en smerte som kan lindres selv om en somheten ikke opphører. Forskning viser at det er en sammenheng mellom ensomhet og risiko for selvmord og selvmordsforsøk, men vi vet lite om hvilke aspekter ved ensomheten som leder til suicidal impulser. Den suicidologiske forskningslitteraturen har til nå korrelert ensomhet til selvmordsrisiko uten å gi en klar definisjon av hva ensomhet er og uten å forklare hvilken rolle ensomhet spiller i forhold til utviklingen av selvmordsrisiko.

O pplevelsen av ensomhet har ikke noe eget fysisk uttrykk, men manifesterer seg gjennom andre følel ser som for eksempel nedstemthet, sinne, frustrasjon eller smerte. Ensomhet er ingen lidelse, men snarere et fenomen som av mange blir be traktet som et problemområde og et tabu. Kanskje ensomhetens "usynlighet" og stigma har bidratt til at forskningen i stedet for å sette et klart fokus på ensomhet som fenomen heller behandler ensomhet i sammenheng med, eller som en del av, andre kjente risikofaktorer for sel vmord? Erfaring tilsier at suicidalimpulser kan reduseres ved å lindre ensomhet. Derfor er det et behov for mer forskning omkring en somhet som risikofaktor for selvmord som en del av det selvmordsforebyggende arbeidet.

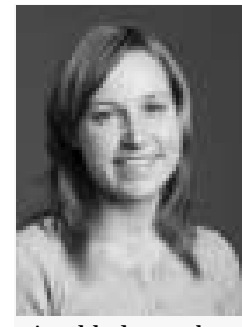

Elin A nita Fadum er cand.med.vet. og arbeider som seniorkonsulent ved SSSFF. Hun har tatt Videreutdanning i sel vmordsforebyggende arbeid ved $\mathrm{U} \mathrm{i} O$. Under studiet fordypet hun seg $\mathrm{i}$ temaet ensomhet og sel vmordsfare.

A rtikkelen er basert på hennes fordypningsoppgave "K an Kirkens SOS forebygge selvmord ved å lindre ensomhet?"

\section{Referanser}

Barstad, A (2004). Få isolerte, men mange er plaget av ensomhet. Samfunn sspeilet, 5, 19-26.

Baumeister, R. F. \& Leary, M. R. (1995). T he need to belong: desire for interpersonal attachments as a fundamental human motivation. Psychological Bulletin, 117, 497-529.

Borge, L, M artinsen, E. W, Ruud, T, Watne, $\varnothing, \&$ Friis, S. (2000). Livskvalitet, ensomhet og sosial kontakt hos mennesker med langvarige psykiske lidelser. Tidsskr N or Lægeforen, 120, 52-55.

Bunch, J. (1972). R ecent bereavement in relation to suicide. Journal of Psychosomatic Research, 16, 361-366.

C arter, G. L., Clover, K., W hyte, I. M ., D awson, A. H., \& D'Este, C. (2005). Postcards from the $E D$ ge project: randomised controlled trial of an intervention using postcards to reduce repetition of hospital treated deliberate self poisoning. BM J, 331, 805.

Durkheim, E. (2001). Selvmordet - en sosiologisk undersøkelse. Trondheim: $\mathrm{G}$ yldendal (org. publ. 1897).

Ekeberg, $\varnothing . \&$ A argaard, I. (1991). Selvmord og selvmordsforsøk blant eldre. TidsskrN orske Laegeforen, 111, 562-564.

Eriksen, N . (2005). N ye vennemønstre gir mindre ensomhet. $\mathrm{H}$ entet 28.11.2005 fra

http://www.nova.no/?id=9090

Gammon, D. (2000). Er Internett til hjelp for personer med alvorlige psykiske lidelser. Tidsskr $\mathrm{N}$ or lægeforen, 120, 1890-1892.

G Iosli, $\varnothing$. (2002). K risetelefon - et ledd i mangfoldet av selvmordsforebyggende tiltak.

I L. M ehlum (red.), Tilbake til livet. K ristiansand: $\mathrm{H} ø y s k o l$ eforlaget A S.

G uneriussen, W. (1997). É mile D urkheims sosiologiske selvmordsteori. Suicidologi, 3, 3-5.

$\mathrm{H}$ alvorsen, K. (2005). Ensomhet og sosial isolasjon i vår tid. 0 slo: G ylden dal $\mathrm{A}$ kademisk.

H eikkinen, M . (1994). R ecent life events, social support and suicide. A cta Psychiatrica Scandinavica.Supplementum, 377, 65-72.

Joiner, T. E., jr. \& Rudd, M . D. (1996). D isentangling the interrelations between hopelessness, loneliness, and suicidal ideation. Suicide Life Threat.Behav., 26, 19-26.

Karnick, P. M . (2005). Feeling lonely: theoretical perspectives. N ursing Science Q uarterly, 18, 7-12.

Ref. forts. s. 27 


\section{Referanser - Fadum}

(forts.)

Kirkens SOS. (2005). Statistikk for Kirkens SOS. [Upublisert arbeid]

Løgstrup, K. E. (1999). Den etiske fordring. Oslo: Cappelen.

Long, J. Ch and Averill, J. R. (2003). Solitude: An exploration of benefits of being alone. Journal for the Theory of Social Behaviour, 331, 21-44.

Motto, J. A. \& Bostrom, A. G. (2001). A randomized controlled trial of postcrisis suicide prevention. Psychiatric Services, 52, 828-833.

Nilsson, B. (2004). Savnets tone i ensomhetens melodi. Åbo: Åbo Akademis förlag.

Pierce, L. L., Wilkinson, L. K., \& Anderson, J. (2003). Analysis of the concept of aloneness. As applied to older women being treated for depression. Journal of Gerontological Nursing, 29, 20-25.

Retterstøl, N., Ekeberg, Ø., \& Mehlum, L. (2002). Selvmord - et personlig og samfunnsmessig problem. Oslo: Gyldendal Akademisk.

Rokach, A. \& Brock, H. (1998). Coping with loneliness. The Journal of Psychology, 132, 107-127.

Rokach, A. (1990). Surviving and coping with loneliness. Journal of Psychology, 124, 39-54.

Rossow, I. (2004). Suicidal atferd - endringer fra 1992 til 2002. Tidsskrift for ungdomsforskning, 4, 77-85.

Stravynski, A. \& Boyer, R. (2001). Loneliness in relation to suicide ideation and parasuicide: a population-wide study. Suicide Life Threat.Behav., 31, 32-40.

Thorsen, K. (2005). Ensomhet blant eldre, selvmordsrisiko og utfordringer. Suicidologi, 10, 4-10.

Vijayakumar, L. (2002). Religion - en beskyttende faktor ved selvmord. Suicidologi, 2, 9-12.

Yalom, I. D. (2000). Eksistentiel psykoterapi. København: Hans Reitzels forlag. 